\title{
Retraction Note to: Artificial neural networks to prediction total specific pore volume of geopolymers produced from waste ashes
}

\author{
Ali Nazari ${ }^{1} \cdot$ Shadi Riahi ${ }^{1}$
}

Published online: 7 May 2020

(c) Springer-Verlag London Ltd., part of Springer Nature 2020

\section{Retraction Note to: Neural Comput \& Applic (2013) 22:719-729} https://doi.org/10.1007/s00521-011-0760-x

The Editor-in-Chief has retracted this article [1] because it significantly overlaps with a large number of articles that were under consideration at the same time, including [2-5], and previously published articles, including [6]. Additionally, the article shows evidence of peer review manipulation. The authors have not responded to any correspondence regarding this retraction.

\section{References}

1. Nazari A, Riahi S (2013) Artificial neural networks to prediction total specific pore volume of geopolymers produced from waste ashes. Neural Comput Appl 22:719-729. https://doi.org/10.1007/ s00521-011-0760-x

2. Nazari A, Khalaj G, Riahi S, Bohlooli H, Kaykha MM (2012) Prediction total specific pore volume of geopolymers produced from waste ashes by ANFIS. Ceram Int 38(4):3111-3120. https:// doi.org/10.1016/j.ceramint.2011.12.011

3. Nazari A, Khalaj G (2012) Prediction total specific pore volume of geopolymers produced from waste ashes by fuzzy logic. Mater Res 15(2):242-252. https://doi.org/10.1590/S1516-1439201200500 0010

4. Bohlooli H, Nazari A, Khalaj G, Kaykha MM, Riahi S (2012) RETRACTED: Experimental investigations and fuzzy logic modeling of compressive strength of geopolymers with seeded fly ash and rice husk bark ash. Compos Part B Eng 43(3):1293-1301. https://doi.org/10.1016/j.compositesb.2012.01.012

5. Nazari A, Riahi S, Khalaj G, Bohlooli H, Kaykha MM (2012) RETRACTED: Prediction of compressive strength of geopolymers with seeded fly ash and rice husk-bark ash by gene expression programming. Int J Damage Mech 21(8):1202-1226. https://doi. org/10.1177/1056789511431991

6. Nazari A, Riahi S (2012) RETRACTED: Experimental investigations and ANFIS prediction of water absorption of geopolymers produced by waste ashes. J Non-Cryst Solids 358(1):40-46. https:// doi.org/10.1016/j.jnoncrysol.2011.08.022

Publisher's Note Springer Nature remains neutral with regard to jurisdictional claims in published maps and institutional affiliations.
The original article can be found online at https:// doi.org/10.1007/s00521-011-0760-x.

\section{Ali Nazari}

alinazari84@aut.ac.ir

1 Department of Materials Science and Engineering, Saveh Branch, Islamic Azad University, Saveh, Iran 